\section{経過に合わせた介入目標により適切な栄養管理 を行なえた小児症例}

○吉田都 ${ }^{1)}$ 、内田洋一朗 ${ }^{2,10)}$ 、富 謙伸 ${ }^{1)}$ 、本田 憲胤 ${ }^{1)}$ 、 猪崎 愛 ${ }^{1,10)}$ 、松岡 森 ${ }^{1,10)}$ 、御石 絢子 ${ }^{3,10}$ 、

山田 信子 ${ }^{3,10)}$ 、井下 春美 ${ }^{4,10)}$ 、北出 順子 ${ }^{4,10)}$ 、 宮森 理英子 ${ }^{4,10)}$ 、松本 忍 ${ }^{4,10)}$ 、垣内 真子 ${ }^{5,10)}$ 、 山崎 みどり ${ }^{5,10)}$ 、宮内 由利子 ${ }^{6,10)}$ 、阿部 恵 ${ }^{7,10)}$ 、 本庶 祥子 ${ }^{7,10)}$ 、熊倉 啓 ${ }^{8)}$ 、佐藤 正人 ${ }^{9,10)}$

1）(公財）田附興風会医学研究所北野病院リハビリテーショ ン科

2）（公財）田附興風会医学研究所北野病院消化器外科

3）(公財）田附興風会医学研究所北野病院栄養部

4）（公財）田附興風会医学研究所北野病院看護部

5）(公財）田附興風会医学研究所北野病院臨床検査部

6）(公財）田附興風会医学研究所北野病院薬剤部

7）(公財）田附興風会医学研究所北野病院糖尿病内分泌内科

8）（公財）田附興風会医学研究所北野病院小児科

9）（公財）田附興風会医学研究所北野病院小児外科

10）（公財）田附興風会医学研究所北野病院栄養サポートチーム

【目的】多職種による NST 介入の有用性が報告されて いるが、急性期病院の小児科領域における NST の関 わりについての報告は少ない。今回、治療介入に工夫 を要した小児科領域の症例を経験したので報告する。

【症例】16 歳男児。入院時身長 $164.5 \mathrm{~cm}$ 、体重 $85.2 \mathrm{~kg}$ 、 BMI31.5kg $/ \mathrm{m}^{2}$ 。超低出生体重児 $(966 \mathrm{~g})$ であり、未 熟児網膜症、自閉症スペクトラム障害、注意欠陥・多 動性障害、肥満による脂肪肝、閉塞性睡眠時無呼吸症 候群の併存があり、小児科にてフォローされていた。頭 痛および呼吸苦を認め、当院救急搬送され緊急入院と なった。同日夜、突然の酸素飽和度低下 $\left(\mathrm{SpO}_{2} 50\right.$ 60\% 台）に続き心停止をきたし、心肺蘇生により心拍 再開し、挿管による呼吸管理および循環動態管理目的 でICU入室となった。入院後 2 日目に殿部の褛瘡を認め、 裖瘡チームが介入開始、4 日目より経腸栄養が開始され、 5 日目に理学療法開始となった（四肢 ROM エクササイ ズ・筋力トレーニング）。11日目に気管切開を行い、全 身状態の改善に伴い 23 日目に小児 HCU へ転室となっ た。全身状態は軽快傾向であったが、経口摂取は厳し い状況であり、経腸栄養による下痢症状のために理学 療法の継続も困難となった。今後の栄養管理が本患児 の重要課題であり、30 日目に NST 介入開始に至った。

NST では、経腸栄養剤の種類変更ならびに注入速度の 調整、水分量の調整、整腸剂の使用を提案し、経時的 に便性状は改善、排便回数は減少し、裖瘡も治癒傾向 となった。48日目より経口摂取（嚥下訓練食（嚥下調 整食学会分類 $20130 \mathrm{j}$ レベル) ) 開始となり、52 日目に は経腸栄養の終了に至った。栄養状態の改善に伴い理 学療法介入時間は増加し、57 日目より階段練習開始、 63 日目頃より歩行介助量は軽減し、112 日目より屋外歩 行練習開始となり、ADL は段階的に拡大した。経口摂 取が安定した 66 日目以降、清涼飲料水の多飲や間食 が増加したため肥満に対する栄養サポートへ変更し、 併せて母親への食事指導を実施した。定期的な NST 介入ならびに積極的な理学療法の継続により、体重は 入院時に比べ約 $20 \mathrm{~kg}$ 減少し、体組成は骨格筋量 $-1.7 \mathrm{~kg}$ 、体脂肪量 $-5.6 \mathrm{~kg}$ となり、ADL は見守りにて平 地歩行ならびに階段昇降が可能となった。入院 154 日目、 自宅退院となった。

【まと】経過に合わせた介入目標の変更により適切な 栄養管理が可能となり、裖瘡の改善および体重減量に つながった。本症例を通して NST における PT の必要 性や役割につき議論したい。
術後口腔がん患者に対する運動療法と栄養管理 に関する症例検討

○田中 孝平 ${ }^{1)}$ 、峠田 彩乃 ${ }^{1)}$ 、山田 知輝 ${ }^{2)}$ 、柏木 宏彦 ${ }^{1)}$

1) 大阪警察病院リハビリテーション技術科

2) 大阪警察病院 ER・救命救急科

【背景】手術侵襲にともなう生体反応だけでなく、 身体活動量や摂取エネルギー量の低下なども骨格筋 量を低下させる要因となるため、術後の運動療法や 栄養管理は周術期ケアの一部として重要な役割を担 う。今回、口腔がん患者の体組成の変化に注目して 術後の運動療法と栄養療法について検討した。

【方法】当院で口腔がんに対して手術治療（切除お よび皮弁）を受け、術前 ADL が自立していた患者 3 名（男性 1 名）を対象とした。体組成の測定には 体成分分析装置を使用し、体重、骨格筋量、体脂肪 量を記録した。また、大腿直筋抒よび中間広筋の筋 厚を超音波診断装置で測定した。観察期間は手術前 日から術後 28 日までとし、各評価項目は手術前日 と術後から 7 日毎に計 5 回測定した。また、術後の 摂取エネルギー量および摂取タンパク質量は 1 日毎 に記録した。

【結果】 3 症例とも術後の栄養投与は経鼻胃管での 経腸栄養 (EN) で開始され、理学療法は術翌日か ら実施。症例 1 は術翌日から EN を開始し、術後 8 日までにエネルギー量は $30 \mathrm{kcal} / \mathrm{kg} / \mathrm{day}$ 、タンパク 質量は $1.3 \mathrm{~g} / \mathrm{kg} / \mathrm{day}$ に増加。離床は術後 5 日から 開始。体重、体脂肪量、大腿筋厚は術後緩やかに低 下し、骨格筋量は概ね横ばいで経過した。症例 2 も 術翌日から EN が開始され、術後 5 日にはエネル ギー量 $31 \mathrm{kcal} / \mathrm{kg} / \mathrm{day} 、$ タンパク質量 $1.3 \mathrm{~g} / \mathrm{kg} / \mathrm{day}$ に増加されたが、嘔気などの理由で EN はしばしば 中断された。離床は術後 6 日から開始。術後の体重、 骨格筋量、体脂肪量は緩やかに低下。大腿筋厚も術 後 14 日までは減少したが、その後増加に転じた。 症例 3 は術部の状態が不良だったため EN と離床は 術後 7 日から開始。EN は術後 14 日にエネルギー 量 $47 \mathrm{kcal} / \mathrm{kg} / \mathrm{day}$ 、タンパク質量 $2.2 \mathrm{~g} / \mathrm{kg} / \mathrm{day}$ に増 加。術後の体脂肪量は概ね横ばいで経過。体重と骨 格筋量は緩やかに低下したが、術後 21 日から 28 日 にかけて増加。大腿筋厚は術後 14 日まで減少したが、 その後大幅に増加した。

【考察】症例 1 は早期に栄養投与と離床が開始され、 体組成の変化が最も少なかった。症例 2 は EN が中 断されたこともあり一時的に筋萎縮が生じた。症例 3 は離床や $\mathrm{EN}$ 開始が最も遅く、大腿筋厚が最も減 少したが、その後は積極的な栄養管理によって体組 成の改善を認めた。

【結論】運動療法や栄養管理の工夫によって、術後 の筋萎縮を軽減できる可能性がある。 